\title{
Genetic variations in the Myostatin gene affecting growth traits in sheep
}

\author{
Noha M. Osman ${ }^{(1 D}$, Heba I. Shafey ${ }^{1}$ (D), Mohamed A. Abdelhafez ${ }^{1}$ (D) Ahmed M. Sallam²(i) and Karima F. Mahrous ${ }^{1}$ (D) \\ 1. Department of Cell Biology, National Research Centre, El Buhouth Street, 12311, Dokki, Egypt; 2. Animal and Poultry \\ Production Division, Desert Research Center, 11753, Mataryia, Egypt. \\ Corresponding author: Karima F. Mahrous, e-mail: mahrouskf3@yahoo.com \\ Co-authors: NMO: osman.noha@yahoo.com, HIS: poohdode@yahoo.com, MAA: banhawy09@yahoo.com, \\ AMS: ahmedsallam2@gmail.com \\ Received: 10-10-2020, Accepted: 15-12-2020, Published online: 23-02-2021
}

doi: www.doi.org/10.14202/vetworld.2021.475-482 How to cite this article: Osman NM, Shafey HI, Abdelhafez MA, Sallam AM, Mahrous KF (2021) Genetic variations in the Myostatin gene affecting growth traits in sheep, Veterinary World, 14(2): 475-482.

\begin{abstract}
Background and Aim: Sheep productivity in developing countries is crucial, as this animal is an essential source of meat and wool. Myostatin (MSTN) plays an important role in the regulation of muscle mass through the regulation of muscle growth, differentiation, and regeneration. The present study sought to investigate genetic variation in the first intron of the MSTN gene and the association of variants with growth traits in major sheep breeds in Egypt (Barki, Ossimi, and Rahmani) and Saudi Arabia (Najdi) using polymerase chain reaction (PCR) and sequencing.

Materials and Methods: Blood samples were collected, and DNA was extracted from 75 animals. A 386 bp fragment in the first intron of the MSTN gene was amplified using PCR. Polymorphic sites were detected using direct sequencing and then correlated with growth traits using a general linear model.

Results: Sequence analysis of the first intron of MSTN gene identified six single-nucleotide polymorphisms (SNPs) in the studied breeds. Four mutual SNPs were determined: c.18 G>T, c.241 T>C, c.243 G>A, and c.259 G>T. In addition, two SNPs c.159 A>T and c.173 T>G were monomorphic (AA and TT, respectively) in the Ossimi, Rahmani, and Najdi breeds and polymorphic in the Barki breed. The association analysis revealed that the c.18 $\mathrm{G}>\mathrm{T}$ and c.241 C>T significantly associated $(\mathrm{p}<0.05)$ with birth weight and average daily weight gain, respectively.
\end{abstract}

Conclusion: Our results strongly support MSTN as a candidate gene for marker-assisted selection in sheep breeding programs. Furthermore, the identified variants may be considered as putative markers to improve growth traits in sheep.

Keywords: growth traits, Myostatin gene, polymorphism, sheep.

\section{Introduction}

Sheeparean essential component of the agricultural sector in Egypt, as well as worldwide. Conventionally, sheep supply small and marginal breeders with meat, milk, and wool products. In Egypt, sheep are an important source of meat production, contributing approximately $6 \%$ of total red meat produced [1]. Based on the total number of sheep, Barki, Ossimi, and Rahmani are the major sheep breeds in Egypt distributed along the western Mediterranean coastal region, the middle of Egypt, and the Northern Nile delta [2]. Substantial variations distinguish between these breeds in phenotypic and productive characteristics [3]. Conversely, Najdi sheep are the prime local breed in the eastern province of Saudi Arabia, and it has the most favorable meat with the most desired taste among all breeds in Saudi Arabia [4].

The performance traits of animals (e.g., growth performance) have a direct impact on the profitability

Copyright: Osman, et al. Open Access. This article is distributed under the terms of the Creative Commons Attribution 4.0 International License (http://creativecommons.org/licenses/ by/4.0/), which permits unrestricted use, distribution, and reproduction in any medium, provided you give appropriate credit to the original author(s) and the source, provide a link to the Creative Commons license, and indicate if changes were made. The Creative Commons Public Domain Dedication waiver (http:// creativecommons.org/publicdomain/zero/1.0/) applies to the data made available in this article, unless otherwise stated. of any animal production enterprise; therefore, these traits have been targeted by several sheep breeding programs in different countries [5]. The genetic basis of any such performance trait should be understood. Growth performance as a quantitative trait is controlled by many genes, one of which is Myostatin $(M S T N)[6]$.

MSTN, also known as growth and differentiation factor 8 , is a member of the transforming growth factor- $\beta$ superfamily and acts as a negative regulator of skeletal muscle growth [7]. It is located at the end of the long arm of chromosome 2 (2q32.2) in sheep (Ovis aries) and comprises three exons and two introns [8]. It has previously been recommended as a candidate gene to improve muscle production in sheep [9]. Moreover, the association of MTSN polymorphisms with several muscle-related traits has been reported in other livestock, such as cattle [10], chickens [11], horses [12], and rabbits [13]. Importantly, the "double-muscling phenomenon" observed in different species is a result of mutations in MSTN that disrupts its expression, resulting in a completely non-functional protein. This has great potential to enhance muscle growth, leading to dramatic muscularity [14-16].

Association analysis using single-nucleotide polymorphisms (SNPs) is the most effective approach to identify genetic markers potentially related to a 
trait of interest [17]. This involves screening candidate genes, which may be biologically related to the desired trait, for putative mutations, and consequently correlating these results with accurate phenotypes of a group of individuals $[18,19]$. The identified genetic markers may be useful in selection and breeding programs in livestock [20]. Variations in the non-coding regions of the MSTN gene have been found to relate to muscle growth and meat quality traits in sheep [21,22], which can be attributed to their effects on the regulatory elements of the gene itself [23].

Several studies have reported that the variations in MSTN have been associated with increased skeletal muscle mass in sheep $[9,24]$ and muscular yield commercially $[25,26]$. Therefore, $M S T N$ in farm animals should be considered to identify the appropriate animals for selection programs, especially marker-assisted selection for economic traits [27]. In this study, a combination of polymerase chain reaction (PCR) and DNA sequencing was used to ascertain genetic variation in intron 1 of the MSTN gene in different sheep breeds and their association with growth traits such as birth weight (BW), final weight (FW), and average daily weight gain (ADG).

\section{Materials and Methods}

\section{Ethical approval}

This study does not require ethical approval; however, samples were collected as per standard sample collection procedure without any harm to animals. The authors obtained consent from sheep farm owners for sample collection.

\section{Study period and location}

The samples were collected from August to November 2018 from two animal production farms that belong to the Faculty of Agriculture, Ain Shams University, and the Faculty of Agriculture, Al-Azhar University, Egypt. DNA isolation, PCR and Sequence analysis were carried out from December 2018 to August 2019.

\section{Animals and blood sampling}

The present study was conducted on 75 animals, including 60 animals from three different Egyptian sheep breeds and 15 animals from a Saudi Arabian Najdi breed. The Egyptian sheep comprised 40 females and 20 males from Barki (17), Rahmani (21), and Ossimi (22) breeds. Barki sheep were maintained at Nubaria Farm, National Research Centre, Egypt. Rahmani and Ossimi sheep were sourced from two animal production farms belonging to the Faculty of Agriculture, Ain Shams University, and the Faculty of Agriculture, Al-Azhar University, Egypt. Phenotypic data including BW, FW at slaughter, and ADG were recorded for each animal of the Egyptian breeds. Finally, blood samples were collected from the jugular veins of all 75 animals in vacuum tubes containing $0.25 \%$ of the anticoagulant ethylenediaminetetraacetic acid. These samples were stored at $-80^{\circ} \mathrm{C}$ until DNA extraction.

\section{DNA extraction}

Using the salting out procedure described by Miller et al. [28], genomic DNA was extracted from whole blood. The DNA concentrations were determined using a NanoDrop 1000 (Thermo Scientific) and then were adjusted to concentrations of $50 \mathrm{ng} / \mu \mathrm{L}$ for PCR.

\section{PCR amplification}

Based on the primers published by Sjakste et al. [23], the following forward and reverse primers were used for PCR amplification of the first intron of the MSTN gene: Forward 5'-GAAACGGTCATTACCATGC-3' and reverse 5'-CATTTGGTTGCCTGAAATATG-3'. The $25 \mu \mathrm{L}$ PCR reaction mixture consisted of $3 \mu \mathrm{L}(150 \mathrm{ng})$ template DNA, $1 \mu \mathrm{L}$ forward primer $(10 \mu \mathrm{M}), 1 \mu \mathrm{L}$ reverse primer $(10 \mu \mathrm{M}), 12.5 \mu \mathrm{L} 2 \times$ PCR master mix, and $7.5 \mu \mathrm{L}$ nuclease-free water. The reaction was cycled at the following conditions: Initial denaturation for $5 \mathrm{~min}$ at $94^{\circ} \mathrm{C}$, followed by 35 cycles of denaturation at $94^{\circ} \mathrm{C}$ for $1 \mathrm{~min}$, annealing at $62^{\circ} \mathrm{C}$ for $1 \mathrm{~min}$, and extension at $72^{\circ} \mathrm{C}$ for $1 \mathrm{~min}$, and a final extension for $5 \mathrm{~min}$ at $72^{\circ} \mathrm{C}$. The PCR product was analyzed by electrophoresis on $2 \%$ agarose gel.

\section{Sequence analysis and SNPs identification}

Purified PCR products were sequenced by Macrogen, Incorporated (South Korea) using forward and reverse primers. The specificity of the nucleotide sequences was determined using Basic Local Alignment Search Tool (BLAST, https://blast.ncbi. nlm.nih.gov/Blast.cgi) [29]. Sequences were analyzed through multiple alignments using Clustal Omega (https://www.ebi.ac.uk/Tools/msa/clustalo/) [30] to determine polymorphic sites, which were confirmed through the visual examination of sequence charts.

\section{Statistical analysis}

The association between identified MSTN genotypes and the studied traits was determined using the general linear model process in SAS (SAS Version 8.2, SAS Institute, Cary, NC). The following model was used to assess the significance of associations:

$$
\mathrm{Y}_{\mathrm{ijk}}=\mu+\mathrm{B}_{\mathrm{i}}+\mathrm{G}_{\mathrm{j}}+\mathrm{H}_{\mathrm{k}}+\mathrm{e}_{\mathrm{ijk}} \text {, }
$$

Where, $\mathrm{Y}_{\mathrm{ijk}}=$ the trait of interest $(\mathrm{BW}, \mathrm{FW}$, and ADG); $\mu=$ the overall mean; $B_{i}=$ the fixed effect of the breed ( 3 levels); $\mathrm{G}_{0}=$ the fixed effect of the $i^{\text {th }}$ genotype corresponds to each SNP independently; $\mathrm{H}_{\mathrm{k}}=$ the fixed effect of the $k^{\text {th }}$ sex of animal (2 levels); and $\mathrm{e}_{\mathrm{ijk}}=$ random error. The random error was assumed to be normally distributed with a mean equal zero and variance equals $\delta_{e}^{2}$.

\section{Results}

\section{Descriptive statistics}

Table-1 presents the estimates of least square means \pm standard deviations and minimum and maximum BW, FW, and ADG for the studied breeds. In general, BW ranged from 2.5 to $4.1 \mathrm{~kg} ; \mathrm{FW}$, from 37 to $63 \mathrm{~kg}$; and $\mathrm{ADG}$, from 68 to $142 \mathrm{~g}$ /day. A higher 
Table-1: Descriptive statistics of the studied traits.

\begin{tabular}{lcccc}
\hline Trait $^{1}$ & Average & SD $^{\mathbf{2}}$ & Minimum & Maximum \\
\hline Barki & & & & \\
BW (kg) & 2.93 & 0.29 & 2.5 & 3.2 \\
FW (kg) & 43.62 & 6.1 & 37 & 53 \\
ADG (g/day) & 90.125 & 11.97 & 68 & 104 \\
Rahmani & & & & \\
BW (kg) & 3.4 & 0.54 & 2.8 & 4.1 \\
FW (kg) & 51.58 & 8.3 & 43 & 63 \\
ADG (g/day) & 98.83 & 28.62 & 75 & 142 \\
Ossimi & & & & \\
BW (kg) & 3.46 & 0.28 & 3 & 3.8 \\
FW (kg) & 48.11 & 5.76 & 41 & 56 \\
ADG (g/day) & 100.66 & 23.76 & 78 & 131 \\
\hline
\end{tabular}

${ }^{1} \mathrm{BW}=$ Birth weight $(\mathrm{kg}), \mathrm{FW}=$ Full weight $(\mathrm{kg})$,

$A D G=$ Average daily gain $(\mathrm{g} /$ day $) . S^{2}=$ Standard deviation

average BW was observed in Rahmani sheep (3.4 kg) and Ossimi sheep (3.46 kg) than in Barki sheep $(2.93 \mathrm{~kg})$. Similarly, the FW was higher in Rahmani sheep $(51.58 \mathrm{~kg})$ and Ossimi sheep $(48.11 \mathrm{~kg})$ than in Barki sheep (43.62 kg). Similarly, a higher ADG was observed in Rahmani sheep (98.83 g/day) and Ossimi sheep (100.66 g/day) than in Barki sheep (90.12 g/day).

\section{Effect of breed and sex}

Analyses of variance indicated that neither the fixed effect of the breed nor the sex of the animal had significant effects $(\mathrm{p}<0.05)$ on the BW. The breed tended to have a significant effect $(\mathrm{p}=0.07)$ on $\mathrm{FW}$, whereas the sex of the animal had a highly significant effect on the FW ( $p=0.001)$. Similarly, the breed did not affect ADG, although sex had a significant effect $(p=0.002)$ on $A D G$, as male lambs had a significantly higher ADG than female lambs.

\section{MSTN variation in the studied breeds}

PCR amplification produced a 386 bp PCR product from the first intron of the MSTN gene in different sheep breeds, including Barki (accession no. MT361503), Ossimi (accession no. MT361504), Rahmani (accession No. MT361505), and Najdi (accession no. MT361506). These sequences were analyzed to detect SNPs in the studied sheep breeds (Figure-1A and B). FourSNPs were detected: c.18 $\mathrm{G}>\mathrm{T}$, c.241 T>C, c.243 G>A, and c.259 G>T. The most interesting SNPs detected were c.159 A>T and c. $173 \mathrm{~T}>\mathrm{G}$, which showed one genotype $(100 \%$ AA and 100\% TT, respectively) (monomorphism) in Ossimi, Rahmani, and Najdi sheep and different genotypes (polymorphism) in Barki sheep (Table-2). Table-3 presents the genotypic and allelic frequencies of MSTN variants in the studied sheep breeds.

\section{Effect of MSTN genotype on the studied traits}

Among the six identified SNPs across the amplified region of MTSN in the three Egyptian sheep breeds, two SNPs tended to significantly influence one of the studied traits. The SNP c.18 G>T (rs119102825, also known as c. $373+18 \mathrm{G}>\mathrm{T}$ ) and SNP c. $241 \mathrm{~T}>\mathrm{C}$ ( $r$ s 119102826, also known as c. $373+241 \mathrm{~T}>\mathrm{C}$ ) showed significant associations with $\mathrm{BW}(\mathrm{p}=0.05)$ and $\mathrm{ADG}$ $(p=0.03)$, respectively. Lambs that carried the GG genotype at position 18 tended to have higher BW $(3.55 \mathrm{~kg}$ ) compared with other genotypes, whereas the TT carriers at position 241 tended to have higher ADG (101 g/day) compared with other genotypes. The rest of the SNPs did not show any significant association with the studied traits (Table-4).

\section{Discussion}

MSTN encodes a negative growth factor that inhibits both the terminal differentiation of myoblasts and the proliferation of myogenic cells $[31,32]$. It was reported as a candidate gene for improved muscle growth in livestock [33], which is positively correlated with the growth performance of the animal. Two mutations in the gene were identified with high frequency as muscular hypertrophy alleles in Belgian Blue and Piedmontese cattle. Polymorphisms were also reported in this gene in different sheep breeds worldwide $[9,21-23,34,35]$. Subsequently, these reports attempted to correlate these variants with important growth and carcass traits of such breeds. Similarly, Shafey et al. [36], Othman et al. [37] reported genetic polymorphisms in the MSTN gene in Egyptian sheep. To the best of our knowledge, our results show the first association between these polymorphisms and growth performance in Egyptian sheep breeds. Moreover, we report novel and breed-specific variants in the Egyptian major sheep breeds.

Growth performance is a complex trait that is likely to be regulated by multiple genes. Therefore, it is always of primary concern in breeding schemes to determine an animal's breeding value [38]. In general, identifying genetic markers for growth traits are an initial and crucial step to establish a marker-assisted selection system [39]. The main determinants of fast growth in mammals are increased muscle cell growth and proliferation. In general, the estimates of growth traits included in the present study were consistent with those reviewed by Elshennawy [40] for the same breeds. However, slightly higher estimates were reported in Barki sheep by Sallam [41] (3.33 kg and $140 \mathrm{~g}$ /day compared with $2.93 \mathrm{~kg}$ and $90.125 \mathrm{~g}$ /day for BW and ADG, respectively, in the present study).

Despite the tendency of the sex of the animal to influence growth traits in sheep [37,42], these effects were not significant in our results for BW. This may be due to the limited sample size population used in the present study. In agreement, the sex of the animal had no significant effect on the growth traits in other sheep breeds such as the Moghani breed [43]. Conversely, other studies have reported a significant effect of sex on growth traits $[37,44]$. However, phenotypic variations were observed between breeds in $\mathrm{BW}$, as Rahmani and Ossimi sheep had higher BW than did Barki sheep. These breed and sex differences in FW were significant, in agreement with those reported by Othman et al. [37]. 
Allele A

Allele_B

Allele A

Allele_B

Allele A

Allele B

Allele A

Allele $B$

Allele_A

Allele_B

Allele_A

Allele B

Allele_A

Allele_B

GTGAGTAGTTCTGCTAGgGCAGAGCAACGACTCTGCTGACTGCTGTTCTAGTGTTCATGA GTGAGTAGTTCTGCTAGTGCAGAGCAACGACTCTGCTGACTGCTGTTCTAGTGTTCATGA

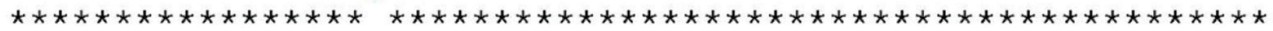

GAAACCGATCTATTTTCAGGCTCTTTTAACAAGCTGCTGGCTTGTACGTAAGGAGGAGGG GAAACCGATCTATTTTCAGGCTCTTTTAACAAGCTGCTGGCTTGTACGTAAGGAGGAGGG $* * * * * * * * * * * * * * * * * * * * * * * * * * * * * * * * * * * * * * * * * * * * * * * * * * * * * * * * * * * *$

CAAAGAGCTTTTTGCAAGACTTCATGAGAAATATGCTAATGAGACTGAAAGCTGCTACAT CAAAGAGCTTTTTGCAAGACTTCATGAGAAATATGCTATTGAGACTGAAAGCGGCTACAT

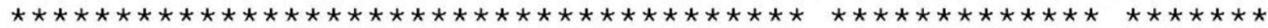

TATCTGTTTCCTTAGAGAGCTAAAAAGCTAAAAATCAGAAATGAAATGCTTGCATAGCAT TATCTGTTTCCTTAGAGAGCTAAAAAGCTAAAAATCAGAAATGAAATGCTTGCATAGCAT

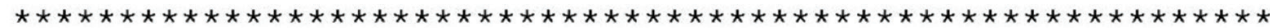

TCGTGTTATATAGTTTAGGATGACAACTATAACATGTTTATGTTTTCACAGCTTAATGCT CCATGTTATATAGTTTAGTATGACAACTATAACATGTTTATGTTTTCACAGCTTAATGCT

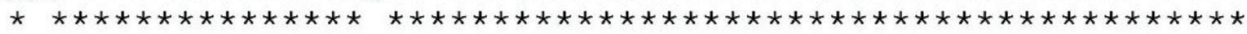

ACCAAGGTGAAGGATTGGGAGACAGTAGCAGCCATGTGAAAAATTTACATGAAATTTCCT ACCAAGGTGAAGGATTGGGAGACAGTAGCAGCCATGTGAAAAATTTACATGAAATTTCCT

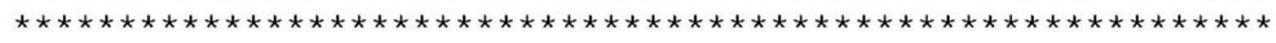

60

60

120 120

180 180

Figure-1A: Polymerase chain reaction product sequences of two different alleles in Egyptian Braki sheep, showing singlenucleotide polymorphisms positions in red color.

Allele A

Allele_B

Allele A

Allele_B

Allele A

Allele_B

Allele A

Allele_B

Allele A

Allele_B

Allele A

Allele_B

Allele A

Allele_B
AATTGCATTTGGTTGCCTGAAATATG

AATTGCATTTGGTTGCCTGAAATATG

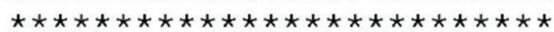

386

386
GTGAGTAGTTCTGCTAGGGCAGAGCAACGACTCTGCTGACTGCTGTTCTAGTGTTCATGA GTGAGTAGTTCTGCTAGTGCAGAGCAACGACTCTGCTGACTGCTGTTCTAGTGTTCATGA $\star * * * * * * * * * * * * * * * * * * * * * * * * * * * * * * * * * * * * * * * * * * * * * * * * * * * * * * * * * *$

GAAACCGATCTATTTTCAGGCTCTTTTAACAAGCTGCTGGCTTGTACGTAAGGAGGAGGG GAAACCGATCTATTTTCAGGCTCTTTTAACAAGCTGCTGGCTTGTACGTAAGGAGGAGGG

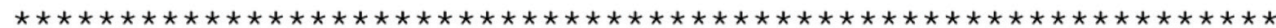

CAAAGAGCTTTTTGCAAGACTTCATGAGAAATATGCTAATGAGACTGAAAGCTGCTACAT CAAAGAGCTTTTTGCAAGACTTCATGAGAAATATGCTAATGAGACTGAAAGCTGCTACAT

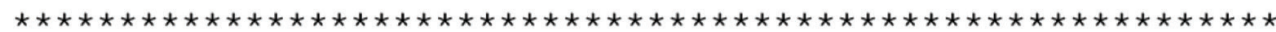

TATCTGTTTCCTTAGAGAGCTAAAAAGCTAAAAATCAGAAATGAAATGCTTGCATAGCAT TATCTGTTTCCTTAGAGAGCTAAAAAGCTAAAAATCAGAAATGAAATGCTTGCATAGCAT $* * * * * * * * * * * * * * * * * * * * * * * * * * * * * * * * * * * * * * * * * * * * * * * * * * * * * * * * * * * *$

TCGTGTTATATAGTTTAGGATGACAACTATAACATGTTTATGTTTTCACAGCTTAATGCT CCATGTTATATAGTTTAGTATGACAACTATAACATGTTTATGTTTTCACAGCTTAATGCT

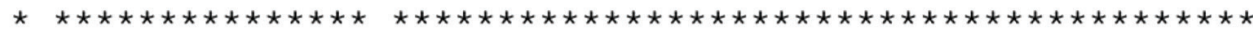

ACCAAGGTGAAGGATTGGGAGACAGTAGCAGCCATGTGAAAAATTTACATGAAATTTCCT ACCAAGGTGAAGGATTGGGAGACAGTAGCAGCCATGTGAAAAATTTACATGAAATTTCCT $* * * * * * * * * * * * * * * * * * * * * * * * * * * * * * * * * * * * * * * * * * * * * * * * * * * * * * * * * * * *$

60

60

120 120

180 180 AATTGCATTTGGTTGCCTGAAATATG 386

Figure-1B: Polymerase chain reaction product sequences of two different alleles in Egyptian (Ossimi and Rahmani) and Saudi Arabia (Najdi) sheep breeds, showing single-nucleotide polymorphisms positions in red color. 
Table-2: SNPs positions and genotype frequencies detected in MSTN intron 1 of different sheep breeds.

\begin{tabular}{|c|c|c|c|c|c|c|}
\hline SNP position & SNPs & Barki (\%) & Ossimi (\%) & Rahmani (\%) & Najdi (\%) & Chromatogram \\
\hline c. $18 \mathrm{G}>\mathrm{T}$ & $\begin{array}{l}\text { GG } \\
\text { GT } \\
\text { TT }\end{array}$ & $\begin{array}{l}39 \\
47 \\
14\end{array}$ & $\begin{array}{l}33 \\
49 \\
18\end{array}$ & $\begin{array}{l}44 \\
45 \\
11\end{array}$ & $\begin{array}{l}31 \\
49 \\
20\end{array}$ & 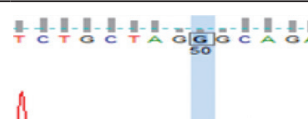 \\
\hline c. $159 \mathrm{~A}>\mathrm{T}$ & $\begin{array}{l}\text { AA } \\
\text { AT } \\
T T\end{array}$ & $\begin{array}{c}69 \\
28 \\
3\end{array}$ & $\begin{array}{c}100 \\
0 \\
0\end{array}$ & $\begin{array}{c}100 \\
0 \\
0\end{array}$ & $\begin{array}{c}100 \\
0 \\
0\end{array}$ & $\underset{G}{1} C_{C}^{1} \underset{190}{1}+A_{A}$ \\
\hline c. $173 \mathrm{~T}>\mathrm{G}$ & $\begin{array}{l}\text { TT } \\
\text { TG } \\
\text { GG }\end{array}$ & $\begin{array}{c}69 \\
28 \\
3\end{array}$ & $\begin{array}{c}100 \\
0 \\
0\end{array}$ & $\begin{array}{c}100 \\
0 \\
0\end{array}$ & $\begin{array}{c}100 \\
0 \\
0\end{array}$ & \\
\hline c. $241 \mathrm{~T}>\mathrm{C}$ & $\begin{array}{l}\text { TT } \\
\text { TC } \\
\text { CC }\end{array}$ & $\begin{array}{l}39 \\
47 \\
14\end{array}$ & $\begin{array}{c}64 \\
32 \\
4\end{array}$ & $\begin{array}{c}56 \\
38 \\
6\end{array}$ & $\begin{array}{l}20 \\
49 \\
31\end{array}$ & 早言合 \\
\hline c. $243 \mathrm{G}>\mathrm{A}$ & $\begin{array}{l}\text { GG } \\
\text { GA } \\
\text { AA }\end{array}$ & $\begin{array}{l}39 \\
47 \\
14\end{array}$ & $\begin{array}{c}64 \\
32 \\
4\end{array}$ & $\begin{array}{c}56 \\
38 \\
6\end{array}$ & $\begin{array}{l}20 \\
49 \\
31\end{array}$ & \\
\hline c. $259 \mathrm{G}>\mathrm{T}$ & $\begin{array}{l}\text { GG } \\
\text { GT } \\
T T\end{array}$ & $\begin{array}{l}39 \\
47 \\
14\end{array}$ & $\begin{array}{l}33 \\
49 \\
18\end{array}$ & $\begin{array}{l}44 \\
45 \\
11\end{array}$ & $\begin{array}{l}20 \\
49 \\
31\end{array}$ & $\underset{\text { TATAGTTTA }}{\|}$ \\
\hline
\end{tabular}

SNPs=Single-nucleotide polymorphisms, MSTN=Myostatin

The previous studies $[22,45]$ showed that the exons and 3'-untranslated regions of MSTN were monomorphic in the studied sheep breeds. Conversely, our screening of the first exon of the MSTN gene showed polymorphism in the studied breeds, which was in agreement with Gan [21], Clop et al. [46], who reported that the first intron of the ovine MSTN gene was highly polymorphic in different sheep breeds. Hickford et al. [35] detected polymorphisms in the first intron of the MSTN gene and reported associations between these alleles and carcass traits in New Zealand Romney sheep. Similarly, Sjakste et al. [23] identified several SNPs in the same fragment of the MTSN gene in Latvian Dark head sheep, suggesting that polymorphisms in this non-coding region can affect regulatory elements.

In this study, genetic diversity analysis revealed that four mutual polymorphic sites were detected in four different sheep breeds (Barki, Ossimi, Rahmani,
Table-3: Genotypic and allelic frequencies of Myostatin variants in the studied sheep breeds.

\begin{tabular}{lccccc}
\hline SNP & \multicolumn{2}{c}{$\begin{array}{c}\text { Allelic } \\
\text { frequency \% }\end{array}$} & \multicolumn{3}{c}{$\begin{array}{c}\text { Genotypic } \\
\text { frequency } \%\end{array}$} \\
\hline SNPc. 18 G>T & $\mathrm{G}$ & $\mathrm{T}$ & $\mathrm{GG}$ & $\mathrm{GT}$ & $\mathrm{T}$ \\
Barki & 63 & 37 & 39 & 47 & 14 \\
Ossimi and Rahmani & 63 & 37 & 39 & 47 & 14 \\
SNPC. 159 A>T & $\mathrm{A}$ & $\mathrm{T}$ & $\mathrm{AA}$ & $\mathrm{AT}$ & $\mathrm{TT}$ \\
Barki & 83 & 17 & 69 & 28 & 3 \\
Ossimi and Rahmani & 100 & 0 & 100 & 0 & 0 \\
SNPc. 173 T>G & $\mathrm{T}$ & $\mathrm{G}$ & $\mathrm{TT}$ & $\mathrm{TG}$ & $\mathrm{GG}$ \\
Barki & 83 & 17 & 69 & 28 & 3 \\
Ossimi and Rahmani & 100 & 0 & 100 & 0 & 0 \\
SNPc. 241 T>C & $\mathrm{T}$ & $\mathrm{C}$ & $\mathrm{TT}$ & $\mathrm{TC}$ & $\mathrm{CC}$ \\
Barki & 63 & 37 & 39 & 47 & 14 \\
Ossimi and Rahmani & 76 & 24 & 55 & 36 & 9 \\
SNPc. 243 G>A & $\mathrm{G}$ & $\mathrm{A}$ & $\mathrm{GG}$ & $\mathrm{GA}$ & $\mathrm{AA}$ \\
Barki & 63 & 37 & 39 & 47 & 14 \\
Ossimi and Rahmani & 76 & 24 & 55 & 36 & 9 \\
SNPc. 259 G>T & $\mathrm{G}$ & $\mathrm{T}$ & $\mathrm{GG}$ & $\mathrm{GT}$ & $\mathrm{T}$ \\
Barki & 63 & 37 & 39 & 47 & 14 \\
Ossimi and Rahmani & 63 & 37 & 39 & 47 & 14
\end{tabular}


Table-4: Effect of the Myostatin gene genotypes on growth traits in Egyptian sheep.

\begin{tabular}{|c|c|c|c|}
\hline \multirow[t]{2}{*}{ Genotype } & \multicolumn{3}{|c|}{ Trait (LS means \pm standard error) } \\
\hline & BW & FW & ADG \\
\hline \multicolumn{4}{|c|}{ SNP c. $18 \mathrm{G}>\mathrm{T}$} \\
\hline GG & $3.55 \pm 0.04$ & $51.56 \pm 1.31$ & $100.96 \pm 2.26$ \\
\hline GT & $3.12 \pm 0.05$ & $47.87 \pm 0.86$ & $101.67 \pm 2.73$ \\
\hline$\pi$ & $3.22 \pm 0.08$ & $49.07 \pm 0.71$ & $98.49 \pm 4.18$ \\
\hline Significance & $0.05 *$ & 0.06 & 0.62 \\
\hline \multicolumn{4}{|c|}{ SNP c. $241 \mathrm{~T}>\mathrm{C}$} \\
\hline $\mathrm{CC}$ & $3.32 \pm 0.05$ & $49.07 \pm 0.83$ & $85.86 \pm 4.12$ \\
\hline CT & $3.22 \pm 0.06$ & $47.87 \pm 1.00$ & $97.62 \pm 4.83$ \\
\hline$\pi$ & $3.45 \pm 0.09$ & $51.56 \pm 1.53$ & $101.13 \pm 7.61$ \\
\hline Significance & 0.11 & 0.13 & $0.03 *$ \\
\hline \multicolumn{4}{|c|}{ SNPC. $243 \mathrm{G}>\mathrm{A}$} \\
\hline GG & $3.23 \pm 0.03$ & $42.20 \pm 0.6$ & $97.90 \pm 1.85$ \\
\hline AG & $3.31 \pm 0.06$ & $48.14 \pm 1.06$ & $103.84 \pm 3.18$ \\
\hline AA & $3.32 \pm 0.07$ & $49.00 \pm 1.20$ & $102.88 \pm 3.86$ \\
\hline Significance & 0.72 & 0.8 & 0.18 \\
\hline \multicolumn{4}{|c|}{ SNP c. 259 G>T } \\
\hline GG & $3.25 \pm 0.03$ & $49.00 \pm 0.60$ & $97.91 \pm 1.80$ \\
\hline GT & $3.31 \pm 0.06$ & $48.41 \pm 1.04$ & $103.84 \pm 3.18$ \\
\hline$\pi$ & $3.32 \pm 0.07$ & $49.20 \pm 1.20$ & $102.82 \pm 3.86$ \\
\hline Significance & 0.72 & 0.81 & 0.18 \\
\hline \multicolumn{4}{|c|}{ SNP c. 159 A>T } \\
\hline GG & $3.24 \pm 0.21$ & $48.94 \pm 0.80$ & $99.90 \pm 2.53$ \\
\hline GT & $3.54 \pm 0.21$ & $51.68 \pm 3.56$ & $100.51 \pm 11.17$ \\
\hline$\pi$ & $3.31 \pm 0.04$ & $48.98 \pm 0.81$ & $100.51 \pm 11.17$ \\
\hline Significance & 0.51 & 0.57 & 0.96 \\
\hline \multicolumn{4}{|c|}{ SNP c. $173 \mathrm{~T}>\mathrm{G}$} \\
\hline GG & $3.27 \pm 0.33$ & $46.54 \pm 5.42$ & $99.91 \pm 3.86$ \\
\hline GT & $3.54 \pm 0.133$ & $51.68 \pm 5.36$ & $100.51 \pm 17.00$ \\
\hline$\pi$ & $3.30 \pm 0.07$ & $48.98 \pm 1.23$ & $100.51 \pm 17.00$ \\
\hline Significance & 0.75 & 0.78 & 0.96 \\
\hline
\end{tabular}

${ }^{1} \mathrm{BW}=$ Birth weight $(\mathrm{kg}), \mathrm{FW}=$ Full weight $(\mathrm{kg})$, $A D G=$ Average daily gain ( $g /$ day). *Significance level $(p<0.05)$

and Najdi) at nucleotide positions G18, T241, G243, and G259 after sequencing the amplified fragments. Consistently, polymorphisms in the first intron of the MSTN gene were identified in the Iranian Makuei sheep breed [47] and in the Kamieniec and Pomeranian sheep breeds [28]. By contrast, Soufy et al. [48] reported that the first intron was monomorphic, and all samples showed the same genotypes in Sanjabi sheep; similarly, Nada et al. [49] reported that all samples of the Egyptian (Barki, Ossimi, and Rahmani) and Saudi (Najdi and Harri) breeds showed the same genotype for exon 3 of the MTSN gene. However, Sahu [50] reported the first variations in exon 3 of the MSTN gene in Nilagiri sheep in South Africa, such as g.5622 $\mathrm{G}>\mathrm{C}$. Interestingly, the c.159 $\mathrm{A}>\mathrm{T}$ mutation showed polymorphism between an $\mathrm{A}$ and a $\mathrm{T}$ allele in Barki sheep, whereas it was monomorphic (AA) in Ossimi, Rahmani, and Najdi breeds. Similarly, polymorphism at c.173 $\mathrm{T}>\mathrm{G}$ showed three different genotypes (TT, TG, and GG) in Barki and one genotype (TT) in the other breeds examined. This may explain the higher heterozygosity in this breed. Similarly, higher heterozygosity has been reported in the Barki breed than in the Ossimi and Rahmani breeds [36]. Higher genetic diversity observed in the present study may be due to the intensive crossing processes in Barki sheep in comparison with other breeds. Moreover, this higher variability in the genetics of Barki has made this breed to be more adapted to the harsh conditions of the Egyptian desert, which is the predominant region in which this breed is cultivated [51]. Increasing the sample size may find additional polymorphisms in subsequent analyses [41].

Rather than relying on traditional breeding approaches to improve the growth traits in sheep, adopting genetic markers are an efficient adjunct tool to successfully achieve this improvement [20]. Reportedly, variants in the non-coding regions of the genome can influence phenotypes by affecting gene regulation $[22,23]$; for example, G/T transversion at c. $373+18$ could functionally affect transcript splicing. Polymorphisms in the non-coding region of MSTN were reported to affect growth and carcass traits $[21,34,35]$ in different sheep breeds worldwide. Consistently, the two SNPs (rs119102825 and rs 119102826) identified in this study were previously reported as significantly associated variants with several growth traits in several sheep breeds both in New Zealand sheep [9] and in Polish Merino sheep [22]. Accordingly, our results suggest that polymorphisms within MSTN significantly influence growth traits in the Egyptian sheep breeds.

\section{Conclusion}

In the present study, we shed light on the MSTN gene as a potential promising genetic marker to improve growth traits in the major sheep breeds in Egypt. Sequence analysis of the first intron of the MSTN gene identified six SNPs in the studied breeds. Four mutual SNPs were identified: c.18 G>T, c.241 $\mathrm{T}>\mathrm{C}$, c.243 G>A, and c.259 G>T, as well as two SNPs c. $159 \mathrm{~A}>\mathrm{T}$ and $\mathrm{c} .173 \mathrm{~T}>\mathrm{G}$ that were monomorphic (AA and TT, respectively) in the Ossimi, Rahmani, and Najdi breeds and polymorphic in the Barki breed. Association analysis revealed that c. $18 \mathrm{G}>\mathrm{T}$ and c. 241 $\mathrm{C}>\mathrm{T}$ significantly associated $(\mathrm{p}<0.05)$ with $\mathrm{BW}$ and ADG, respectively. Our results suggest that polymorphisms within MSTN significantly influence growth traits in the Egyptian sheep breeds. We strongly recommend reanalyzing MSTN variants using larger sample sizes to detect these polymorphisms and increasing the power of the current investigation.

\section{Authors' Contributions}

KFM conceived the idea and designed the experiment. NMO performed DNA sequence and variants analysis. AMS performed statistical analysis. HIS and MAA performed the experiments. KFM, NMO, HIS, and AMS wrote the manuscript. All the authors revised, read, and approved the final manuscript.

\section{Acknowledgments}

The authors like to thank Cell Biology Department, the National Research Centre, Egypt, 
for providing necessary facilities for this study. The authors did not receive any funds for this study.

\section{Competing Interests} interests.

The authors declare that they have no competing

\section{Publisher's Note}

Veterinary World remains neutral with regard to jurisdictional claims in published institutional affiliation.

\section{References}

1. El Fiky, Z.A., Hassan, G.M. and Nassar, M.I. (2017) Genetic polymorphism of growth differentiation factor 9 (GDF9) gene related to fecundity in two Egyptian sheep breeds. J. Assist. Reprod. Genet., 34(12): 1683-1690.

2. Galal, S., Abdel-Rasoul, F., Anous, M.R. and Shaat, I. (2005) On station characterization of small ruminant breeds in Egypt. In: Iniguez, L.C., editor. Characterization of Small Ruminant Breeds in West Asia and North Africa. Vol. 2. Aleppo, Syria, International Center for Agricultural Research in the Dry Areas (ICARDA), Lebanon, p141-193.

3. Abdel-Moneim, A.Y. (2009) Body and carcass characteristics of Ossimi, Barki and Rahmani ram lambs raised under intensive production system. Egypt. J. Sheep Goat Sci., 4(2): $1-16$

4. Aljumaah, R.S., Al-Shaikh, M.A., Kibogo, H., Kwallah, A., Jianlin, H., Hanotte, O., Musthafa, M.M. and Marikar, F.M.M. (2014) Genetic relationships among four Saudi Arabian sheep populations. Iran. J. Appl. Anim. Sci., 4(4): 775-779.

5. Amare, T., Goshu, G. and Tamir, B. (2018) Flock composition, breeding strategies and farmers' traits of interest evaluation of Wollo highland sheep and their F 1 crosses. J. Anim. Sci. Technol., 60(14): 9.

6. Crispo, M., Mulet, A.P., Tesson, L., Barrera, N., Cuadro, F., dos Santos-Neto, P.C., Nguyen, T.H., Creneguy, A., Brusselle, L., Anegon, I. and Menchaca, A. (2015) Efficient generation of myostatin knock-out sheep using CRISPR/ Cas9 technology and microinjection into zygotes. PLoS One, 10(8): e0136690.

7. McPherron, A.C., Lawler, A.M. and Lee, S.J. (1997) Regulation of skeletal muscle mass in mice by a new TGFbeta superfamily member. Nature, 387(6628): 83-90.

8. Hadjipavlou, G., Matika, O., Clop, A. and Bishop, S.C. (2008) Two single nucleotide polymorphisms in the myostatin (GDF8) gene have significant association with muscle depth of commercial Charollais sheep. Anim. Genet., 39(4): 346-353.

9. Han, J., Forrest, R.H. and Hickford, J.G. (2013) Genetic variations in the myostatin gene (MSTN) in New Zealand sheep breeds. Mol. Biol. Rep., 40(11): 6379-6384.

10. Casas, E. and Kehrli, M.E. Jr. (2016) A review of selected genes with known effects on performance and health of cattle. Front. Vet. Sci., 3(113): 1-11.

11. Zhang, X.X., Ran, J.S., Lian, T., Li, Z.Q., Yang, C.W., Jiang, X.S., Du, H.R., Cui, Z.F. and Liu, Y.P. (2019) The single nucleotide polymorphisms of myostatin gene and their associations with growth and carcass traits in Daheng broiler. Braz. J. Poult. Sci., 21(3): 0808.

12. Dall'Olio, S., Fontanesi, L., Nanni Costa, L., Tassinari, M., Minieri, L. and Falaschini, A. (2010) Analysis of horse myostatin gene and identification of single nucleotide polymorphisms in breeds of different morphological types. J. Biomed. Biotechnol., 2010: 542945.

13. Guo, R., Wan, Y., Xu, D., Cui, L., Deng, M., Zhang, G., Jia, R., Zhou, W., Wang, Z., Deng, K., Huang, M., Wang, F. and Zhang, Y. (2016) Generation and evaluation of Myostatin knock-out rabbits and goats using CRISPR/Cas9 system. Sci. Rep. 6 (29855): $1-10$.

14. Amthor, H., Macharia, R., Navarrete, R., Schuelke, M., Brown, S.C., Otto, A., Voit, T., Muntoni, F., Vrbova, G., Partridge, T., Zammit, P., Bunger, L. and Patel, K. (2007) Lack of myostatin results in excessive muscle growth but impaired force generation. Proc. Natl. Acad. Sci. U. S. A., 104(6): 1835-1840.

15. Deng, B., Zhang, F., Wen, J., Ye, S., Wang, L., Yang, Y., Gong, P. and Jiang, S. (2017) The function of myostatin in the regulation of fat mass in mammals. Nutr. Metab., 14 (29): 1-6.

16. Grade, C.V.C., Mantovani, C.S. and Alvares, L.E. (2019) Myostatin gene promoter: Structure, conservation and importance as a target for muscle modulation. J. Anim. Sci. Biotechnol., 10(32): 1-19.

17. Fan, B., Du, Z.Q., Gorbach, D.M. and Rothschild, M.F. (2010) Development and application of high-density SNP arrays in genomic studies of domestic animals. Asian Aust. J. Anim. Sci., 23(7): 833-847.

18. Kwon, J.M. and Goate, A.M. (2000) The candidate gene approach. Alcohol. Res. Health, 24(3): 164-168.

19. Sallam, A.M., Zare, Y., Shook, G., Collins, M. and Kirkpatrick, B.W. (2018) A positional candidate gene association analysis of susceptibility to paratuberculosis on bovine chromosome 7. Infect. Genet. Evol., 65: 163-169.

20. Sallam, A.M., Gad-Allah, A.A. and Al-Bitar, E.M. (2020) Association analysis of the ovine KAP6-1 gene and wool traits in Barki sheep. Anim. Biotechnol., DOI: 10.1080/10495398.2020.1749064.

21. Gan, S.Q., Du, Z., Liu, S.R., Yang, Y.L., Shen, M., Wang, X.H., Yin, J.L., Hu, X.X., Fei, J., Fan, J.J., Wang, J.H., He, Q.H., Zhang, Y.S. and Li, N. (2008) Association of SNP haplotypes at the myostatin gene with muscular hypertrophy in sheep. Asian Aust. J. Anim. Sci., 21(7): 928-935.

22. Grochowska, E., Borys, B. and Mroczkowski, S. (2019) Effects of intronic SNPs in the myostatin gene on growth and carcass traits in colored Polish merino sheep. Genes (Basel), 11(1): 2.

23. Sjakste, T., Paramonova, N., Grislis, Z., Trapina, I. and Kairisa, D. (2011) Analysis of the single-nucleotide polymorphism in the 5'UTR and part of intron I of the sheep MSTN gene. DNA Cell. Biol., 30(7): 433-444.

24. Boman, I.A., Klemetsdal, G., Nafstad, O., Blichfeldt, T. and Vage, D.I. (2010) Impact of two myostatin (MSTN) mutations on weight gain and lamb carcass classification in Norwegian White Sheep (Ovis aries). Genet. Sel. Evol., 42(1): 4.

25. Yamada, A.K., Verlengia, R. and Bueno Junior, C.R. (2012) Myostatin: Genetic variants, therapy and gene doping. Braz. J. Pharm. Sci., 48(3): 369-377.

26. Zhang, C., McFarlane, C., Lokireddy, S., Masuda, S., Ge, X., Gluckman, P.D., Sharma, M. and Kambadur, R. (2012) Inhibition of myostatin protects against diet-induced obesity by enhancing fatty acid oxidation and promoting a brown adipose phenotype in mice. Diabetologia, 55(1): 183-193.

27. Kolenda, M., Grochowska, E., Milewski, S. and Mroczkowski, S. (2019) The association between the polymorphism in the myostatin gene and growth traits in Kamieniec and Pomeranian sheep breeds. Small Ruminant Res., 177: 29-35.

28. Miller, S.A., Dykes, D.D., Polesky, H.F., (1988) A simple salting out procedure for extracting DNA from human nucleated cells. Nucleic Acids Res. 16: 1215.

29. Altschul, S.F., Gish, W., Miller, W., Myers, E.W. and Lipman, D.J. (1990) Basic local alignment search tool. J. Mol. Biol., 215(3): 403-410.

30. Thompson, J.D., Higgins, D.G. and Gibson, T.J. (1994) CLUSTAL W: Improving the sensitivity of progressive multiple sequence alignment through sequence weighting, 
position-specific gap penalties and weight matrix choice. Nucleic Acids Res., 22(22): 4673-4680.

31. Thomas, M., Langley, B., Berry, C., Sharma, M., Kirk, S., Bass, J. and Kambadur, R. (2000) Myostatin, a negative regulator of muscle growth, functions by inhibiting myoblast proliferation. J. Biol. Chem., 275(51): 40235-40243.

32. Wiener, P., Woolliams, J.A., Frank-Lawale, A., Ryan, M., Richardson, R.I., Nute, G.R., Wood, J.D., Homer, D. and Williams, J.L. (2009) The effects of a mutation in the myostatin gene on meat and carcass quality. Meat. Sci., 83(1): 127-134.

33. Kambadur, R., Sharma, M., Smith, T.P. and Bass, J.J. (1997) Mutations in myostatin (GDF8) in double-muscled Belgian blue and Piedmontese cattle. Genome Res., 7(9): 910-916.

34. Kijas, J.W., McCulloch, R., Edwards, J.E., Oddy, V.H., Lee, S.H. and van der Werf, J. (2007) Evidence for multiple alleles effecting muscling and fatness at the ovine GDF8 locus. BMC Genet., 8(80): 1-11.

35. Hickford, J.G., Forrest, R.H., Zhou, H., Fang, Q., Han, J., Frampton, C.M. and Horrell, A.L. (2010) Polymorphisms in the ovine myostatin gene (MSTN) and their association with growth and carcass traits in New Zealand Romney sheep. Anim. Genet., 41(1): 64-72.

36. Shafey, H.I., Mahrous, K.F., Hassanane, M.S., Mordy, M.A. and Rushdi, H.E. (2014) Genetic polymorphism of myostatin and insulin-like growth factor binding protein-3 genes in Egyptian sheep breeds. Global Vet., 13(3): 419-424.

37. Othman, O.E., Balabel, E.A. and Mahfouz, E.R. (2016) Genetic characterization of myostatin and callipyge genes in Egyptian small ruminant breeds. Biotechnology, 15(1-2): 44-51.

38. Malik, Z.S., Dalal, D.S., Dahiya, S.P., Patil, C.S. and Dahiya, R. (2016) Genetic analysis of growth traits in Harnali sheep. Vet. World, 9(2): 128-132.

39. Ekegbu, U.J., Burrows, L., Amirpour-Najafabadi, H., Zhou, H. and Hickford, J.G.H. (2019) Gene polymorphisms in PROP1 associated with growth traits in sheep. Gene, 683: 41-46.

40. Elshennawy, M. (1995) Sheep development program in Egypt. Gabina D. (ed.). In: Strategies for Sheep and Goat Breeding. Zaragoza, CIHEAM, Spain p27-32.

41. Sallam, A.M., Ibrahim, A.H. and Alsheikh, S.M. (2019) Genetic evaluation of growth in Barki sheep using random regression models. Trop. Anim. Health Prod., 51(7): 1893-1901.

42. Ibrahim, A.H.M. (2019) Association of growth performance and body conformational traits with BMP4 gene variation in Barki lambs. Growth Factors, 37(3-4): 153-163.

43. Lavvaf, A., Noshary, A. and Keshtkaran, A. (2007) Environmental and genetic effects on early growth traits in Moghani sheep breeds. Pak. J. Biol. Sci., 10(15): 2595-2598.

44. Esenbuga, N. and Dayioglu, H. (2002) Effects of some environmental factors on growth traits of Awassi and Redkaraman lambs. Turk. J. Vet. Anim. Sci., 26(1): 145-150.

45. Dehnavi, E., Ahani Azari, M., Hasani, S., Nassiry, M.R., Mohajer, M., Khan Ahmadi, A., Shahmohamadi, L. and Yousefi, S. (2012) Polymorphism of myostatin gene in intron 1 and 2 and exon 3, and their associations with yearling weight, using PCR-RFLP and PCR-SSCP techniques in zel sheep. Biotechnol. Res. Int., 2012: 472307.

46. Clop, A., Marcq, F., Takeda, H., Pirottin, D., Tordoir, X., Bibe, B., Bouix, J., Caiment, F., Elsen, J.M., Eychenne, F., Larzul, C., Laville, E., Meish, F., Milenkovic, D., Tobin, J., Charlier, C. and Georges, M. (2006) A mutation creating a potential illegitimate microRNA target site in the myostatin gene affects muscularity in sheep. Nat. Genet., 38(7): 813-818.

47. Farhadian, M. and Hashemi, A. (2016) Molecular characterization and phylogeny based analysis of intron i sequence of myostatin (MSTN) gene in Iranian Makuei sheep breed. Ann. Anim. Sci., 16(4): 1007-1018.

48. Soufy, B., Mohammadabadi, M.R., Shojaeyan, K., Baghizadeh, A., Ferasaty, S., Askari, N. and Dayani, O. (2009) Evaluation of myostatin gene polymorphism in Sanjabi sheep by PCR-RFLP method. Anim. Sci. Res. 19(1): 81-9.

49. Nada, E., Mahrous, K.F. and Salem, L.M. (2013) Genetic polymorphism detection in four genes in Egyptian and Saudi sheep breeds. World Appl. Sci. J., 27(1): 33-43.

50. Sahu, A.R. (2019) Novel report on mutation in exon 3 of myostatin (MSTN) gene in Nilagiri sheep: An endangered breed of South India. Trop. Anim. Health Prod., 51(7): 1817-1822.

51. Abousoliman, I., Reyer, H., Oster, M., Murani, E., Mourad, M., Rashed, M.A., Mohamed, I. and Wimmers, K. (2020) Analysis of candidate genes for growth and milk performance traits in the Egyptian Barki sheep. Animals (Basel), 10(2): 7. 